\title{
Use of regulators of growth in increase of efficiency of hybrids of sunflower in KBR
}

\author{
Irina Haniyeva*, Rustam Abdulkhalikov, Yury Shogenov, Andemirkan Odizhev, and \\ Ahmed Sabolirov \\ The Kabardino-Balkarian state agricultural university of V. M. Kokov, Lenin Avenue, 1v, 360004, \\ Nalchik, KBR, Russia
}

\begin{abstract}
In a foothill zone of Kabardino-Balkar Republic in 2018-2020 researches on identification of the most effective preparations on crops of sunflower were conducted. As objects of research sunflower hybrids Donskoy 22 F1 served. Donskoy 342 and EU Muse. The following preparations were used: Albite, Polidon Biot Olive. Use of the preparations Albite and Polidon Biot Olive positively influences viability of seeds, duration of the vegetative period, a crop and quality of sunflower. The analysis of the conducted researches showed that cultivation of hybrids of sunflower of the EU the Muse in the conditions of a foothill zone of Kabardino-Balkar Republic is the most favorable.
\end{abstract}

\section{Introduction}

One of the most profitable cultures in modern agriculture is the sunflower. In Russia it is in the greatest demand in comparison with other oil-bearing crops. Oil of sunflower it is most demanded in the food industry. Thus, oil of sunflower has superiority in comparison with soy, palm, rape both on nutritious, and on technological effectiveness.

On food security of Russia the most important link is production of seeds of sunflower. At competent selection of grades of sunflower, biological products, the newest regulators of growth of plants, mineral fertilizers will allow to increase gross collecting this valuable oilbearing crop. Studying of innovative methods of increase of efficiency of hybrids of sunflower in agroecological conditions of Kabardino-Balkar Republic is the most important and hot topic. In nature protection agrarian economy with use of bio products and regulators of growth it is represented especially harmless and successful security measure of plants from wreckers and diseases. Use of biological products is considered harmless to environment, wild and pets of the person, and in particular for useful insects healers and entomophages representatives of a biocenosis domestic scientists filled up in the last decades with new development by products which it is realized by means of a network of shopping centers. These preparations can be useful both to gardeners, and to farmers at their use on plants in fight against diseases and wreckers [5].

Active microorganisms are a part of substances: fungi, bacteria, microbes. Separate new rostostimuliruyushchy preparations, are capable to raise immune system of plants that is

\footnotetext{
${ }^{*}$ Corresponding author: imhanieva@mail.ru
} 
confirmed with numerous researches, to induce their resistance to diseases, thus improving structure and increasing productivity of the cultivated culture. The review of references of researches of the Russian and foreign scientists, allows to conclude that in a question of receiving big crops maslosemyan sunflower it is necessary to use all elements of intensive technology of cultivation of sunflower. In development of resource-saving technologies the essential role is played by new domestic preparations which not only carry out protective function of plants of sunflower and and increase efficiency and its quality indicators. Also they promote decrease in pesticidal load of a field agrobiocenosis that finally leads to increase in profitability of production. [8].

In the Kabardino-Balkarian state agricultural university during 2018-2020 we conducted field experiments in the Criminal Procedure Code of the Kabardino-Balkarian GAU, according to a geographical position the industrial practice complex is in a foothill zone of Kabardino-Balkar Republic. The agrosoil cover is presented by the chernozem lixivious. $[1]$.

Determination of parameters of field viability and growth processes of hybrids of sunflower, research of dependence of productivity and maslichnost of hybrids of sunflower from growth regulators was a research objective, to calculate economic efficiency of use of the studied preparations on crops of sunflower and to reveal the most effective preparations on crops of sunflower

Scientific novelty. In Kabardino-Balkar Republic in a zone of unstable and insufficient moistening influence of regulators of growth of preparations of a domestic production Albite and Polidon Biot Olive, on growth processes, biometric characteristics, productivity and quality of different hybrids of sunflower is for the first time studied.

Practical value. Double processing of crops in phases of 2 couples leaves and blossoming on the lixivious chernozem gave an increase for $24,1 \%$.

\section{Materials and methods of researches}

In a foothill zone of Kabardino-Balkar Republic in 2018-2020 researches on identification of the most effective preparations on crops of sunflower were conducted by Objects of research sunflower hybrids served: Don 22 F1, Donskoy 342, EU Muse. The area of a registration site - 50 square meters, frequency quadruple, placement of options rendomizirovanny [6]. According to a specific goal and tasks the field experiment was put.

Experience 1. Studying of growth, development and formation of efficiency of hybrids of sunflower at introduction on crops of the regulator of growth.

Processing by albite $(40 \mathrm{ml} /$ hectare $)$ and Polidon Biot Olive $(1,5 \mathrm{l} /$ hectare $)$ was carried out during vegetation of sunflower in phases: 2 nd couple real leaves and blossoming.

And - hybrids of B - growth regulators

The Don 22 F1 (st) without regulyatorov1, control

Donskoy 342 Albite

EU Muse Polidon Biot Olive

Agrotechnology in research work standard forthis zone [3], [4].

The predecessor - peas.

- studied growth processes on a scale of BBCH-scale (sunflower) https://ru.qaz.wiki/wiki/BBCH-scale _ (sunflower);

- The area of leaves was defined by method of carvings us [6];

- by a method of the State sortoispytaniye density of standing of plants was defined on hectare and field viability;

- on Kidd, Vest and Briggs's formula was parameters are filled: photosynthetic potential and net productivity of photosynthesis [7];

- on Soksleta fat content was defined by method of the fat-free remains; 
- account of a crop is kept podelyanochno, in terms of conditional humidity of $7 \%$;

- experimental data were processed by method of the dispersive analysis two-factorial;

- experiment [6].

\section{Results and discussion}

On field shoots distinctions in experience with extra root processing by preparations are revealed. Also in genetic characteristics reliable distinctions at sunflower hybrids are revealed. It should be noted that the moment of use of preparations had no essential influence on field viability of hybrids of sunflower (tab. 1).

Table 1. Field viability of hybrids of sunflower, \% (2018-2020.)

\begin{tabular}{|c|c|c|c|}
\hline Factor A - hybrids & control & Albit & $\begin{array}{l}\text { Polydon Bio } \\
\text { Oilseed }\end{array}$ \\
\hline & 2018 & & \\
\hline Donskoy 22 F1 (st) & 82,7 & 82,3 & 82,4 \\
\hline Donskoy 342 & 83,4 & 83,3 & 83,5 \\
\hline \multirow[t]{2}{*}{ EC Muza } & 84,3 & 83,5 & 84,3 \\
\hline & 2019 & & \\
\hline Donskoy 22 F1 (st) & 82,7 & 82,5 & 82,7 \\
\hline Donskoy 342 & 83,2 & 82,9 & 83,2 \\
\hline \multirow[t]{2}{*}{ EC Muza } & 83,6 & 83,8 & 83,8 \\
\hline & 2020 & & \\
\hline Donskoy 22 F1 (st) & 82,2 & 82,1 & 82,2 \\
\hline Donskoy 342 & 81,9 & 82,1 & 81,9 \\
\hline \multirow[t]{2}{*}{ EC Muza } & 82,8 & 83,3 & 82,8 \\
\hline & $\begin{array}{c}\text { Average of 2018- } \\
2020 \\
\end{array}$ & & \\
\hline Donskoy 22 F1 (st) & 82,6 & 82,3 & 82,5 \\
\hline Donskoy 342 & 82,8 & 82,8 & 82,8 \\
\hline EC Muza & 83,6 & 83,6 & 83,6 \\
\hline $\begin{array}{c}\text { NSR } 0.5 \text { for particular } \\
\text { differences }\end{array}$ & & 0,75 & \\
\hline \multicolumn{4}{|l|}{ NSR 0.5 for factor A } \\
\hline NSR 0.5 for factor $B+A B$ & & & \\
\hline
\end{tabular}

The maximum indicator on field viability at a hybrid of sunflower was at the level of $83,1-83,6 \%$, respectively $82,2-82,4 \%$ and $82,7-82,8 \%$ at hybrids Donskoy $22 \mathrm{~F} 1$ and Donskoy 342.

During experiment we revealed more plastic hybrid of sunflower with the EU the Muse which differed on all indicators.

During research phenological researches of growth processes of hybrids of sunflower are conducted. We saw off on the basis of the VVSN international code, are received from macrophases and 99 microphases (table 2). 
Table 2. Duration of macrostages of growth and development of hybrids of sunflower depending on the applied preparations, days (2018-2020).

\begin{tabular}{|c|c|c|c|c|c|c|c|c|}
\hline \multirow[b]{2}{*}{$\begin{array}{l}\text { Factor } \\
\text { In } \\
- \\
\text { preparation } \\
\text { y }\end{array}$} & \multicolumn{8}{|c|}{$\begin{array}{l}\text { Macrostages of growth and developments } \\
\text { (VVSN code) }\end{array}$} \\
\hline & $\begin{array}{l}\text { Macro } \\
\text { tadiya 0: } \\
\text { germination }\end{array}$ & $\begin{array}{l}\text { Macro } \\
\text { tadiya 1: } \\
\text { Developmente } \\
\text { leaves (main } \\
\text { escape) }\end{array}$ & $\begin{array}{l}\text { Macro } \\
\text { tadiya 2: } \\
\text {-Macro } \\
\text { tadiya 3: } \\
\text { Growth } \\
\text { in } \\
\text { length }\end{array}$ & $\begin{array}{l}\text { Macro } \\
\text { tadiya 4: } \\
\text {-Macro } \\
\text { tadiya 5: } \\
\text { Development } \\
\text { e mortgage } \\
\text { to flowers }\end{array}$ & $\begin{array}{l}\text { Makrost } \\
\text { adiya 6: } \\
\text { Blossoming } \\
\text { (main } \\
\text { escape) }\end{array}$ & $\begin{array}{l}\text { Macro } \\
\text { tadiya } \\
7: \\
\text { It is } \\
\text { developed } \\
\text { iye } \\
\text { fruits }\end{array}$ & $\begin{array}{l}\text { Macro } \\
\text { tadiya } \\
8: \\
\text { Having } \\
\text { ripened } \\
\text { aniye } \\
\text { fruits } \\
\text { and } \\
\text { seeds }\end{array}$ & $\begin{array}{l}\text { Makrost } \\
\text { adiya 9: } \\
\text { Dying off }\end{array}$ \\
\hline \multicolumn{9}{|c|}{ Donskoy 22 F1 (st) } \\
\hline control & 8 & 25 & 24 & 7 & 12 & 9 & 12 & 2 \\
\hline Albit & 8 & 26 & 25 & 8 & 12 & 9 & 13 & 3 \\
\hline $\begin{array}{l}\text { Polydon } \\
\text { Bio } \\
\text { Oilseed }\end{array}$ & 8 & 26 & 25 & 8 & 12 & 9 & 13 & 3 \\
\hline \multicolumn{9}{|c|}{ Donskoy 342} \\
\hline control & 8 & 26 & 25 & 7 & 12 & 9 & 12 & 2 \\
\hline Albit & 8 & 28 & 26 & 8 & 12 & 9 & 13 & 3 \\
\hline $\begin{array}{l}\text { Polydon } \\
\text { Bio } \\
\text { Oilseed }\end{array}$ & 8 & 26 & 25 & 8 & 12 & 9 & 13 & 3 \\
\hline \multicolumn{9}{|c|}{ EC Muza } \\
\hline control & 8 & 26 & 25 & 8 & 12 & 9 & 12 & 3 \\
\hline Albit & 8 & 28 & 26 & 8 & 13 & 10 & 13 & 3 \\
\hline $\begin{array}{l}\text { Polydon } \\
\text { Bio } \\
\text { Oilseed }\end{array}$ & 8 & 28 & 26 & 8 & 13 & 10 & 13 & 3 \\
\hline
\end{tabular}

In the presented scale, macrostage 0 is considered 1 macrophase, in which similar physiological processes take place, such as swelling of the grains, the release of the embryo root from the grains, the opening of the cotyledons and the release of the hypocotyl, which ends with the emergence of seedlings. The presented macro stage did not differ in all hybrids and averaged 7 days for all variants of our surveys.

With the release of leaf blades and a stem, the establishment of macro stage 1 is noticed. It is characterized by the absolute opening of the stems, where there are 1-2 pair of full leaves, ends with the release of 9 true leaves At this turn, a discrepancy in the genotypic characteristics of hybrids begins to appear, and the duration of the macro stage is already had differences in the variants of the experiment.

Foliar treatment of crops with substances at the stage of appearance of 2 pairs of leaves was for the Donskoy hybrid 22 - 25-26 days, for the Donskoy 342 hybrid - 26-28 days and for the EU Muse hybrid - 28 days.

A couple of the studied products extended the macro stage by 1 day on average, in particular, the Albit product. For example, it contributed to an increase in the duration of growth processes in all hybrids on average for a day. And the product Polydon Bio Oily acted only on the hybrids of Donskoy 22F1 and EU Muse.

Donskoy 22F1 Donskoy 342 variant without the use of substances, it is about 6 days. The activation of the process of creating generative and reproductive organs was carried out underthe action of the substances under study. Similar tendencies were revealed the other macrostages. Macrostage 9 is considered the final boundary of the growing season of the 
sunflower hybrid. In general, no significant differences were found for the options. The provided macro stage lasted 2-3 days on average.

Similarly, it has been practically confirmed that the duration of the growth processes was largely influenced not by the genetic individualities of the hybrids, but by the foliar treatment of crops with the studied products. In practice, they have a beneficial effect on the adaptation of sunflower plants in the growing environment, which later allowed them to realize their own productive potential.

Duration of the growing season of sunflower plants on treated variants allowed to stock up on more dry matter and nutritious ingredients to create the coming harvest.

The materials presented in table 3 indicate an increase in the duration of the growing season of hybrids with foliar processing of the culture with products.

Table 3. The effect of drugs on the duration of the growing season of sunflower hybrids, days (2018-2020)

\begin{tabular}{|c|c|c|c|}
\hline \multirow[b]{2}{*}{ Factor A - hybrids } & \multicolumn{3}{|c|}{ Factor B - drugs } \\
\hline & control & Albit & $\begin{array}{l}\text { Polydon } \\
\text { Bio Oily }\end{array}$ \\
\hline \multicolumn{4}{|l|}{2018} \\
\hline Donskoy 22 F1(st) & 94 & 94 & 94 \\
\hline Donskoy 342 & 96 & 94 & 96 \\
\hline EC Muza & 97 & 97 & 97 \\
\hline \multicolumn{4}{|l|}{2019} \\
\hline Donskoy 22 F1(st) & 95 & 94 & 95 \\
\hline Donskoy 342 & 97 & 93 & 97 \\
\hline EC Muza & 98 & 98 & 98 \\
\hline \multicolumn{4}{|l|}{2020} \\
\hline Donskoy 22 F1(st) & 92 & 92 & 92 \\
\hline Donskoy 342 & 94 & 93 & 94 \\
\hline EC Muza & 96 & 96 & 96 \\
\hline \multicolumn{4}{|l|}{ Average of 2018-2020 } \\
\hline Donskoy 22 F1(st) & 93 & 93 & 93 \\
\hline Donskoy 342 & 95 & 93 & 95 \\
\hline EC Muza & 97 & 97 & 97 \\
\hline $\begin{array}{l}\text { NSR } 0.5 \text { for particular } \\
\text { differences }\end{array}$ & \multicolumn{3}{|c|}{1,24} \\
\hline NSR 0.5 for factor $\mathrm{A}$ & \multicolumn{3}{|c|}{1,39} \\
\hline $\begin{array}{l}\text { NSR } 0.5 \text { for factor } B+ \\
A B \text { " }\end{array}$ & \multicolumn{3}{|c|}{2,28} \\
\hline
\end{tabular}

The duration of the growing season in the control variants was the shortest in all hybrids. So over the years of research, it averaged 342-95 days for the Donskoy, 97 days for the EU Muse hybrid.

In the crops treated with Albit, the growing season for sunflower plants in the control variant reached 93 days, on Donskoy 342 - also 93 days, for the EU Muse hybrid up to 97 days.Polydon Bio Oily had the same tendency for the duration of the growing season.

Thus, the studied preparations had an insignificant effect on the duration of the growing season of sunflower hybrids. 
Table 4. Dynamics of changes in plant height depending on the drugs used, $\mathrm{cm}$ (2018-2020)

\begin{tabular}{|l|c|c|c|c|}
\hline \multirow{4}{*}{ Macrostages } & \multirow{2}{*}{ Factor B - drugs } & \multicolumn{3}{|c|}{ Factor A - hybrids } \\
\cline { 3 - 5 } & $\begin{array}{c}\text { Donskoy 22 } \\
\text { F1(st) }\end{array}$ & $\begin{array}{c}\text { Donskoy } \\
342\end{array}$ & EC Muza \\
\hline \multirow{4}{*}{$0-3$} & Control & 83,2 & 89,5 & 95,7 \\
\cline { 2 - 5 } & Albit & 101,9 & 106,0 & 112,7 \\
\cline { 2 - 5 } & $\begin{array}{c}\text { Polydon Bio } \\
\text { Oilseed }\end{array}$ & 92,4 & 94,0 & 102,0 \\
\hline \multirow{4}{*}{$4-6$} & Control & 129,1 & 132,5 & 142,1 \\
\cline { 2 - 5 } & Albit & 142,1 & 147,2 & 153,9 \\
\cline { 2 - 5 } & $\begin{array}{c}\text { Polydon Bio } \\
\text { Oilseed }\end{array}$ & 135,1 & 139,8 & 149,4 \\
\hline \multirow{3}{*}{$7-9$} & Control & 151,7 & 153,3 & 158,9 \\
\cline { 2 - 5 } & Albit & 161,5 & 162,8 & 167,0 \\
\cline { 2 - 5 } & $\begin{array}{c}\text { Polydon Bio } \\
\text { Oilseed }\end{array}$ & 156,3 & 159,8 & 160,5 \\
\hline
\end{tabular}

The hybrid EC Muse in all variants was characterized by a higher plant height. The change in the height of sunflower plants was more influenced by the use of the studied preparations in crops than the genotypic characteristics of the hybrids. The studied growth regulators had a positive effect not only on the duration of macro and micro stages of sunflower hybrids. The plant height was also increased in the variants with the use of the preparations Albit and Polydon Bio Oil. According to the hybrid Donskoy 22 F1 (st), the deviation from the standard was 9.8 and 4.7\%, Donskoy $342-11.3$ and 8.1\%, EU Muse 8.1 and $1.5 \%$ (Table 5).

Table 5. Variation of plant height of sunflower hybrids, $\mathrm{cm}$ (2018-2020)

\begin{tabular}{|c|c|c|c|c|c|c|c|c|c|c|c|c|}
\hline \multirow[b]{2}{*}{$\begin{array}{l}\text { Factor } \\
\text { B } \\
\text { drugs }\end{array}$} & \multicolumn{4}{|c|}{ Donskoy 22 F1(st) } & \multicolumn{4}{|c|}{ Donskoy 342} & \multicolumn{4}{|c|}{ EC Muza } \\
\hline & 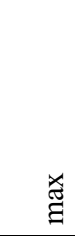 & 声 & 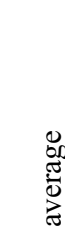 & 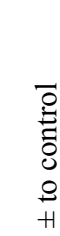 & 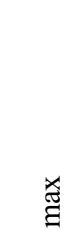 & 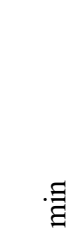 & 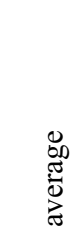 & $\begin{array}{l}\text { D } \\
\stackrel{0}{0} \\
0 \\
0 \\
0 \\
+1\end{array}$ & 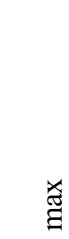 & 寻 & 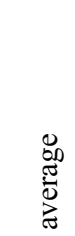 & 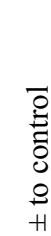 \\
\hline control & $\begin{array}{l}165, \\
7\end{array}$ & $\begin{array}{l}140, \\
2\end{array}$ & $\begin{array}{l}153, \\
4\end{array}$ & $\begin{array}{l}0, \\
0\end{array}$ & $\begin{array}{l}167, \\
3\end{array}$ & $\begin{array}{l}142, \\
7\end{array}$ & $\begin{array}{l}153, \\
4\end{array}$ & 0,0 & $\begin{array}{l}173, \\
2\end{array}$ & $\begin{array}{l}148, \\
3\end{array}$ & $\begin{array}{l}153, \\
4\end{array}$ & $\begin{array}{l}0 \\
0\end{array}$ \\
\hline Albit & $\begin{array}{l}173, \\
3\end{array}$ & $\begin{array}{l}153, \\
5 \\
\end{array}$ & $\begin{array}{l}163, \\
3\end{array}$ & $\begin{array}{l}9 \\
8\end{array}$ & $\begin{array}{l}174, \\
8\end{array}$ & $\begin{array}{l}154, \\
7\end{array}$ & $\begin{array}{l}164, \\
7\end{array}$ & $\begin{array}{l}11, \\
3\end{array}$ & $\begin{array}{l}178, \\
3\end{array}$ & $\begin{array}{l}159, \\
4\end{array}$ & $\begin{array}{l}168, \\
9\end{array}$ & $\begin{array}{l}8, \\
1\end{array}$ \\
\hline $\begin{array}{l}\text { Polydo } \\
\text { n Bio } \\
\text { Oilseed }\end{array}$ & $\begin{array}{l}171, \\
8\end{array}$ & $\begin{array}{l}146, \\
8\end{array}$ & $\begin{array}{l}158, \\
1\end{array}$ & $\begin{array}{l}4, \\
7\end{array}$ & $\begin{array}{l}173, \\
8\end{array}$ & $\begin{array}{l}149 \\
4\end{array}$ & $\begin{array}{l}161, \\
6\end{array}$ & 8,1 & $\begin{array}{l}175, \\
7\end{array}$ & $\begin{array}{l}149, \\
1\end{array}$ & $\begin{array}{l}162 \\
3\end{array}$ & $\begin{array}{l}1, \\
5\end{array}$ \\
\hline $\begin{array}{lr}\text { NSR } & 0 . \\
\text { difference } \\
\text { NSR } & 0.5 \\
\text { NSR } & 0.5\end{array}$ & $\begin{array}{r}\text { for } \\
\text { f facto } \\
r \text { facto }\end{array}$ & $\begin{array}{l}\text { particl } \\
\mathrm{A} \\
\mathrm{B}+\mathrm{A}\end{array}$ & & 32 & & & & & & 0 , & & \\
\hline
\end{tabular}

The collection of sunflower seeds was formed according to all elements of the crop structure - the diameter of the baskets, the mass of achenes in the basket, and the mass of 1000 achenes. They are among the leading traits of seed productivity, which are presented in Table 6. 
Table 6. Influence of biological products on the elements of the structure of the yield of sunflower hybrids (2018-2020)

\begin{tabular}{|c|c|c|c|c|c|c|c|}
\hline \multirow{2}{*}{$\begin{array}{l}\text { Factor A - } \\
\text { hybrids }\end{array}$} & \multirow[t]{2}{*}{ Factor B - drugs } & \multicolumn{2}{|c|}{$\begin{array}{l}\text { Basket } \\
\text { diameter, }\end{array}$} & \multicolumn{2}{|c|}{$\begin{array}{l}\text { The mass of } \\
\text { achenes in the } \\
\text { basket, }\end{array}$} & \multicolumn{2}{|c|}{$\begin{array}{l}\text { Weight of } 1000 \\
\text { hemicarps, }\end{array}$} \\
\hline & & $\mathrm{sm}$ & $\begin{array}{l}\% \text { to } \\
\text { cont. }\end{array}$ & $\mathrm{g}$ & $\begin{array}{l}\% \text { to } \\
\text { cont }\end{array}$ & g & $\begin{array}{l}\% \text { to } \\
\text { cont }\end{array}$ \\
\hline \multirow{3}{*}{$\begin{array}{l}\text { Donskoy } \\
22 \text { F1 (st) }\end{array}$} & Control & 17 & 0,0 & 84,5 & 0,0 & 74,2 & 0,0 \\
\hline & \begin{tabular}{|l|} 
Albit \\
\end{tabular} & 17,9 & 5,3 & 87,4 & 3,4 & 76,1 & 2,6 \\
\hline & \begin{tabular}{|l} 
Polydon Bio Oily \\
\end{tabular} & 17,7 & 4,1 & 86,9 & 2,8 & 75,6 & 1,9 \\
\hline \multirow{3}{*}{$\begin{array}{l}\text { Donskoy } \\
342\end{array}$} & Control & 17,1 & 0,0 & 82,4 & 0,0 & 73,6 & 0,0 \\
\hline & Albit & 18,2 & 6,4 & 86,2 & 4,6 & 75,8 & 3,0 \\
\hline & \begin{tabular}{|l} 
Polydon Bio Oily \\
\end{tabular} & 18,1 & 5,8 & 85,6 & 3,9 & 75,5 & 2,6 \\
\hline \multirow[b]{4}{*}{ EC Muza } & Control & 17,5 & 0,0 & 85,1 & 0,0 & 74,7 & 0,0 \\
\hline & Albit & 18,6 & 6,3 & 88,6 & 4,1 & 76,4 & 2,3 \\
\hline & \begin{tabular}{|l} 
Polydon Bio Oily \\
\end{tabular} & 18,3 & 4,6 & 88 & 3,4 & 76,2 & 2,0 \\
\hline & $\begin{array}{l}\text { NSR } 0.5 \text { for particular } \\
\text { differences } \\
\text { NSR } 0.5 \text { for factor A } \\
\text { NSR } 0.5 \text { for factor B }+ \\
\text { AB }\end{array}$ & 0,48 & & 0,62 & & 1,02 & \\
\hline
\end{tabular}

For all variants, the hybrid EC Muza turned out to be the best with the use of Albit $2.43 \mathrm{t}$ / ha (Table 7). But the reaction of other sunflower hybrids should also be noted.

Table 7. Influence of preparations on sunflower yield, $t /$ ha (moisture content 7\%)

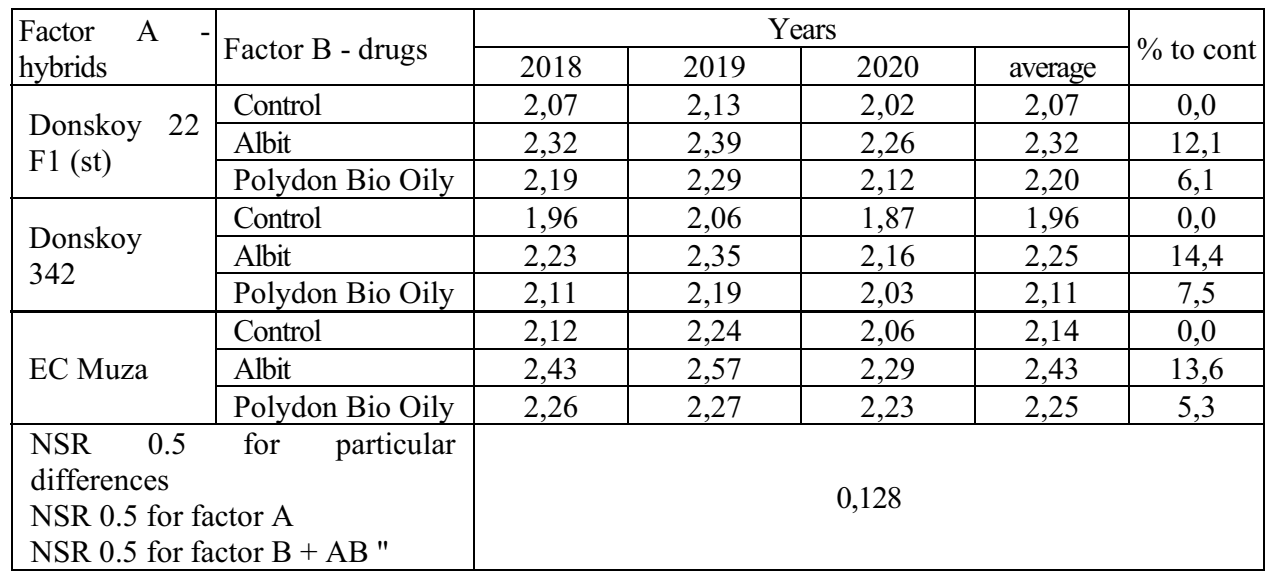

Thus, foliar feeding of sunflower with the studied preparations declared itself as a reserve for increasing seed productivity of sunflower hybrids.

The research work took into account the oil content of the hybrid hemicarps, as well as the collection of oil per hectare of crops (Table 8).

Table 8. Seed oil content and oil collection by sunflower hybrids, (2018-2020)

\begin{tabular}{|l|c|c|c|c|c|}
\hline $\begin{array}{l}\text { Factor } \\
\text { hybrids }\end{array}$ & \multirow{2}{*}{ Factor B - drugs } & \multicolumn{2}{|c|}{ Oiliness } & \multicolumn{2}{c|}{ Oil collection } \\
\cline { 3 - 6 } & & $\%$ & $\%$ to cont. & t/ga & $\%$ to cont. \\
\hline \multirow{2}{*}{$\begin{array}{l}\text { Donskoy } \\
\text { F1 (st) }\end{array}$} & Control & 51,87 & 0,0 & 1,05 & 0,0 \\
\hline & Albit & 52,88 & 1,9 & 1,2 & 14,3 \\
\cline { 2 - 6 } & Polydon Bio Oily & 52,78 & 1,8 & 1,13 & 7,6 \\
\hline Donskoy & Control & 50,75 & 0,0 & 0,96 & 0,0 \\
\hline
\end{tabular}




\begin{tabular}{|l|c|c|c|c|c|}
\cline { 2 - 5 } 342 & Albit & 51,77 & 2,0 & 1,13 & 17,7 \\
\cline { 2 - 5 } & Polydon Bio Oily & 51,56 & 1,6 & 1,06 & 10,4 \\
\hline \multirow{3}{*}{ EC Muza } & Control & 53,19 & 0,0 & 1,09 & 0,0 \\
\cline { 2 - 5 } & Albit & 54,61 & 2,7 & 1,29 & 18,3 \\
\cline { 2 - 5 } & Polydon Bio Oily & 54,3 & 2,1 & \multicolumn{2}{|c|}{1,12} \\
\hline \multirow{2}{*}{$\begin{array}{l}\text { NSR 0.5 for particular differences } \\
\text { NSR 0.5 for factor A }\end{array}$} & \multicolumn{2}{|c|}{$0,10,41$} & \multicolumn{2}{c|}{0,42} \\
\cline { 2 - 5 } NSR 0.5 for factor B + AB " & \multicolumn{2}{|c|}{0,70} \\
\hline
\end{tabular}

As noted above, according to all variants, the EU Muza hybrid turned out to be the best on the variant with the use of the Albit preparation, in terms of oil content, $54.61 \%$, and in terms of oil collection, $1.29 \mathrm{t} / \mathrm{ha}$.

In terms of oil content, the data were, respectively, for the Donskoy 22 hybrid, the deviation from control was 1.9 and 1.8\%., Donskoy $342-2.0$ and 1.6\%, EU Muse 2.7 and $2.1 \%$.

In terms of oil content in the Donskoy 22 hybrid, the difference with the control was 1.9 and $1.8 \%$, Donskoy $342-2.0$ and 1.6\%, EU Muza -2.7 and $2.1 \%$.

In terms of oil collection, for hybrid Donskoy 22, the difference with control was 14.3 and 7.6\%, Donskoy 34217.7 and 10.4\%, EU Muse 18.3 and $9.2 \%$.

In general, the results of the experiments showed that the treatment of crops with the studied products had a positive effect not only on growth processes, but also on the process of crop formation and its quality indicators. It is considered very important to determine the economic efficiency of the studied hybrids and preparations.

Table 9 shows the results that determine the economic efficiency of the experiments.

Table 9. Economic efficiency of the use of drugs on sunflower crops (2018-2020)

\begin{tabular}{|c|c|c|c|c|c|c|}
\hline \multirow[b]{2}{*}{$\begin{array}{l}\text { Factor A - } \\
\text { hybrids }\end{array}$} & \multirow[b]{2}{*}{ Factor B - drugs } & \multicolumn{5}{|c|}{ Indicators } \\
\hline & & $\begin{array}{l}\text { Cost of } \\
\text { production, } \\
\text { thousand } \\
\text { nubles/ha }\end{array}$ & $\begin{array}{l}\text { Productivity, t/ } \\
\text { ha }\end{array}$ & $\begin{array}{l}\text { Conditional } \\
\text { net income, } \\
\text { thousand } \\
\text { nubles / ha }\end{array}$ & $\begin{array}{l}\text { Production } \\
\text { costs, } \\
\text { thousand } \\
\text { nubles } / \text { ha }\end{array}$ & $\begin{array}{l}\text { Level of } \\
\text { profitability, } \\
\%\end{array}$ \\
\hline \multirow{3}{*}{$\begin{array}{l}\text { Donskoy } 22 \\
\text { F1 (st) }\end{array}$} & Control & 14,7 & 2,0 & 7,1 & 7,6 & 93,3 \\
\hline & Albit & 16,4 & 2,3 & 8,6 & 7,8 & 110,4 \\
\hline & Polydon Bio Oily & 15,6 & 2,2 & 7,8 & 7,8 & 100,0 \\
\hline \multirow{3}{*}{ Donskoy 342} & Control & 13,9 & 1,9 & 6,3 & 7,6 & 82,7 \\
\hline & Albit & 15,9 & 2,2 & 8,1 & 7,8 & 103,9 \\
\hline & Polydon Bio Oily & 15,0 & 2,1 & 7,2 & 7,8 & 92,2 \\
\hline \multirow{3}{*}{ EC Muza } & Control & 14,9 & 2,1 & 7,3 & 7,6 & 96,0 \\
\hline & Albit & 17,2 & 2,4 & 9,3 & 7,8 & 119,5 \\
\hline & Polydon Bio Oily & 15,8 & 2,2 & 8,0 & 7,8 & 102,6 \\
\hline
\end{tabular}

As mentioned above, the most productive was the hybrid EU Muza $2.4 \mathrm{t} / \mathrm{ha}$, the cost of production was 17.2 thousand rubles, and the level of profitability was $119.5 \%$.

According to the cost of production, the data were, respectively, for the Donskoy 22 hybrid in the range of 14.7-16.4 thousand rubles, Donskoy 342 - 13.9-15.9 thousand rubles, EU Muse 14.9-17.2 thousand rubles ...

In terms of net income, the following results were obtained - for the hybrid Donskoy 22 in the range of 7.1-8.6 thousand rubles, Donskoy $342-6.3-8.1$ thousand rubles, EU Muse 7.3-9.3 thousand roubles.

In terms of profitability, the data were, respectively, for the hybrid Donskoy 22 within 93.3-110.4\%, Donskoy 342 82.7-103.9\%, EU Muza 96.0-119.5\%.

In the experiment with foliar treatment of sunflower crops with Albit preparations, it was better in all hybrids. 


\section{Conclusion}

In the crops treated with the biological product Albit, the vegetation of the sunflower plant was increased to 91 days compared to the standard, 93 days for the Donskoy 342 hybrid and 95 days for the EU Muza hybrid, the treatment of the Donskoy 342 hybrid with Polydon Bio Oil increased the sunflower vegetation against the background of control, by 4 days, but it was less than in comparison with Albit by one day. In the EU Muza hybrid, the effect of using the studied drugs was similar - 98 days of vegetation.

Treatment of crops during the growing season with the biological product Albit provided an increase in dry matter in the EU Muza hybrid by $0.55 \mathrm{t} /$ ha compared to the control $-6.23 \mathrm{t} / \mathrm{ha}$. The impact of the biological product Polydon Bio Oily was somewhat less $-0.42 \mathrm{t} /$ ha of growth.

In terms of the weight of achenes in the basket, the hybrid EU Muse differed, in fact, which averaged over the years of studies from $82.7 \mathrm{~g}$ in the control variant to $86.1 \mathrm{~g}$ when using the biological product Albit.In the variant Fon + Albit, the average yield over the years of studies was $1.99-2.52 \mathrm{t} / \mathrm{ha}$. The excess over the control variant is equal to 0.26 $0.58 \mathrm{t} /$ ha.

The treatment of crops with drugs contributed to an increase in the oil content of sunflower seeds. The oil content in the Muza hybrid increased by $1.1-1.4 \%$, depending on the preparation. The Muse hybrid was still in the lead in the collection of oil. On control, the collection of oil was $1.07 \mathrm{t} / \mathrm{ha}$. Treatment with Albit gave an increase of $0.21 \mathrm{t} / \mathrm{ha}$ of oil, and for Polydon Bio Oily, $0.10 \mathrm{t} /$ ha of oil.

The cultivation of the EC Muza hybrid turned out to be more profitable 123.6\%, its profitability in the variant with the use of the Albit preparation, which, in comparison with the control, was $24.8 \%$. For the Donskoy 342 hybrid, the difference was about $25.4 \%$, for the Donskoy 22F1 hybrid - 18.2\%.

\section{References}

1. T.B. Zherukov, I.M. Khanieva, A.Yu. Kishev, International scientific research, 2, 120126 (2017)

2. I.M. Khanieva, S.A. Bekuzarova, A method for reducing the incidence of sunflower, Patent for invention No. 2603105 dated 20.11.2016

3. R.I. Shamurzaev, I.M. Khanieva, Reports of the Adyg (Circassian) International Academy of Sciences, 9 (2) 180-182 (2007)

4. I.M. Khanieva, M.M. Kardanova, A.M. Nazarov, R.M. Adamokov, Growing of oil flax in the Kabardino-Balkarian Republic, In the collection: Trends ofmodernscience-2014 "Material sof XII international scientific and practical conference. Editor Michael Wilson, 82-85 (2014)

5. M.Kh. Khaniev, I.M. Khanieva, M.M. Kardanova, Adaptive technology for the cultivation of oil flax in the Kabardino-Balkarian Republic, In the collection: Non-state resource potential for the development of rural areas of Russia Materials of the AllRussian scientific-practical conference with international participation, 126-129 (2015)

6. B.A. Dospekhov, Field experiment methodology (with the basics of statistical processing of research results) (M, Agropromizdat, 351, 1985)

7. A.A. Nichiporovich, A.L. Kursanov, Photosynthesis and Theory of High Yields, (M, Publishing house of the Academy of Sciences of the USSR, 95, 1956)

8. P. Sytie, Biol. Agr. Hortic, 2 (3), 245-269 (1985) 